\title{
Optimization of inhaled therapies for tuberculosis: The role of macrophages and dendritic cells
}

Mercedes González-Juarrerōa, and Mary P. O’Sullivan̄̄, ,

a Mycobacteria Research Laboratories, Department of Microbiology, Immunology and

Pathology, Colorado State University, Fort Collins, CO 80523, USA

b Department of Clinical Medicine, Institute of Molecular Medicine, Trinity College Dublin, St. James's Hospital, Dublin 8, Ireland

Received 30 July 2010;

revised 16 August 2010;

accepted 29 August 2010.

Available online 2 October 2010.

\section{Summary}

Inhaled therapies in the form of drugs or vaccines for tuberculosis treatment were reported about a decade ago. Experts around the world met to discuss the scientific progress in inhaled therapies at the international symposium "Optimization of inhaled Tuberculosis therapies and implications for host-pathogen interactions" held in New Delhi, India on November 3-5, 2009. The meeting was organized by the Central Drug Research Institute (CDRI) Lucknow, India. The lung is the main route for infection with Mycobacterium tuberculosis bacilli and the primary site of reactivation of latent disease. The only available vaccine BCG is relatively ineffective at preventing tuberculosis disease and current therapy requires prolonged treatment with drugs which results in low patient compliance. Consequently, there is a need to design new vaccines and therapies for this disease. Recently there has been increased interest in the development of inhaled formulations to deliver anti-mycobacterial drugs and vaccines directly to the lung and many of these therapies are designed to target lung macrophages and dendritic cells. However, the development of effective inhaled therapies requires an understanding of the unique function and immunosuppressive environment of the lung which is driven, in part, by alveolar macrophages and dendritic cells. In this review, we will discuss the role of alveolar macrophages and dendritic cells in the host immune response to $M$. tuberculosis infection and the ways in which inhaled therapies might enhance the anti-microbial response of phagocytes and boost pulmonary immunity.

Keywords: Tuberculosis; Macrophage; Dendritic cell; Inhaled therapy

stimulate innate bactericidal responses and/or antigen presenting functions more efficiently and will ameliorate drug toxicity due to reduction in dose/duration of treatment. 12 However, the development of successful inhaled therapies in general will depend on the confounding characteristics of the lungs, in addition to the multiple variables added by alterations in its structure and damage inflicted by the inflammatory process, and needs to take into account factors such as aeration of the lungs, deposition and lung function, formation of biofilms and resistance in the face of treatment.[12] and [13] 
The role of alveolar macrophages and dendritic cells in the immuneresponse to

\section{Mycobacterium tuberculosis}

\section{M. tuberculosis infection in the lungs}

Tuberculosis is mainly a disease of the lung and is characterized by a long chronic stage of infection and progressive pathology that compromise the respiratory system. The bacte $\overline{r i a}$ enter through the respiratory route and infect macrophage cell populations in the lung. 14 If the bacteria are not eliminated right away by innate mechanisms of immunity then they multiply and enter the blood stream reaching other organs. M tuberculosis also infects macrophages in the blood, spleen, lymph nodes, liver, kidney, and intestine; in these other organs the pathology can differ significantly from the lung. 14 In a way, it is the special environment of the lung described above that sustains a chronic infection with $M$. tuberculosis and subsequent pathology found in tuberculosis disease.

Once inside the lungs, to establish infection, M. tuberculosis need to traverse the airways and settle in the alveolar spaces where the phagocyte macrophage populations [AM and DCs] are located. The fate of the bacillus within the infecting cell depends on the state of activation of the phagocyte [alternative or classical state of activation] encountering the bacillus. As explained above, the lungs' macrophage populations can be found in multiple phenotypes and stages of differentiation and the survival of the bacillus in the lungs "is a lottery", its fate depending on the type and activation state of the phagocytic cell found in its way. It is believed that the bacillus is able to survive within the macrophage if the phenotype of the phagocytic cell interacting with $\mathrm{M}$. tuberculosis displays an anti-inflammatory phenotype also known as "alternative activation state". Thus, these cells have increased expression of pattern recognition receptors such as the mannose and scavenger receptors facilitating cell and bacillus interaction but they also have a reduced oxidative burst and they are unable to eliminate the bacillus. In Schlesinger's words "They eat but do not influence".[15] and [16]

\section{Activation state of phagocytes, influence of the lung environment and current studies of dry powder formulations affecting phagocyte activation state}

The activation state of the phagocytes within the alveolar spaces appears to be governed by a highly regulated alveolus immune environment. Thus, surfactants found in the alveolar spaces in tuberculosis disease are believed to influence the environment in which the bacilli may establish infection in the lung and are responsible for the maintenance of an alternatively activated alveolar macrophage. [2] and [4] Surfactants, predominately A and D, are released by type II epithelial cells in the alveoli and are routinely taken up and recycled by alveolar macrophages. Surfactant $A$ is taken up by the mannose receptor, dampens the oxidative burst by inhibiting translocation of NADPH oxidase to the phagosome and increases expression of TLR2 and TLR4 on the cell surface. Surfactant protein D on the other hand, inhibits phagocytosis but promotes phagolysosomat fusion of those bacilli that are phagocytosed.[2], [17], [18], [19], [20], [21], [22] and [23] Using mathematical modelling Schlesinger's group has calculated the time required for alternatively activated macrophages to be replaced by classically activated macrophages in the $M$. tuberculosis infected lung; termed "switching time". From this study is was estimated that in mice infected with M tuberculosis it takes approximately 50 days to convert to classically activated macrophages. 24

From the therapeutic viewpoint switching from alternative to classical activation of macrophages in the infected Tung may be achieved by inhalation of microparticles prepared as a dry powder formulation. [13], [25] and [26] This procedure has been demonstrated by Misra's group at CSIR, India to drive infected macrophage towards a more "classical macrophage activation pathway".25 Poly(lactic acid) (PLA) microparticles formulated to carry anti- 
tuberculosis drugs to macrophages in the lung were used as one type of inhaled therapy.26 Unexpectedly, as well as the anti-microbial effects of the antibiotics contained in the microparticles, the particles themselves also triggered innate macrophage microbicidal activity including increased production of reactive oxygen species, nitric oxide and proinflammatory cytokines that is more reminiscent of classical macrophage activation compared to that induced by $\mathrm{M}$. tuberculosis alone. The microparticles also augmented infected macrophage cell death which displayed a phenotype more similar to classical apoptosis (i.e. activation of caspases). Moreover, macrophage activation by blank microparticles was also associated with reduced mycobacterial survival compared to untreated macrophages.

\section{Development of the adaptive immune response against $M$. tuberculosis infection and current immunotherapeutic approaches to delivery into the lungs}

Adaptive immunity to $M$. tuberculosis infection is dependent on the emergence of specific subpopulations of $T$ cells. It is well known that CD4 T cell populations are critical for overcoming this infection[27], [28], [29] and [30] but other cell populations such as CD8 T cells,[31], [32] and [33] $\gamma \delta \mathrm{T}$ cells [34] and [35] and NK cells respond to pulmonary infection with M. tuberculosis. 36 Priming of adaptive immunity towards a Th1 cytokine response (IL-12, IL-23, IFNY, TNF $\alpha$, IL-17) is an essential step to limit multiplication of $M$.

tuberculosis. [37], [38], [39], [40], [41] and [42] Evidence suggests that the mediastinal lymph node cluster draining the lungs is the first organ where priming of a Th1 response against pulmonary infection with $\mathrm{M}$. tuberculosis occurs $\underline{43}$ and is mediated by DCs carrying bacteria to this organ via lymphatic vessels or directly by free bacteria reaching the lymphoid tissues through the lymph fluid or blood.44Primed T cells then are recruited to the lung driven by chemokine gradients where they interact with infected cells and deliver IFNy which ultimately will activate production of microbicidal substances by AM and DCs. In summary, if bacteria are not eliminated by innate mechanisms of immunity then they multiply within the infected cell and it is not until adaptive immunity develops, and provides a supply of IFNy, that the bacterial multiplication is eliminated or contained. The latter leads to a chronic stage of infection characterized by a persistent source of mycobacterial antigens in the lung, sustaining a chronic inflammatory response with a continuous recruitment of monocytes, macrophages (MO) and DCs[7] and [45] as well as T and B lymphocytes [46] and[47] along with a sustained production of several inflammatory cytokines and chemokines.[27] and [48] This inflammatory process develops into a granuloma lesion which helps restrain the surviving bacteria.

Several immunosuppressive diseases or drug immunotherapies have provided additional information about a very important aspect of chronic infection with $M$. tuberculosis, namely that the containment of $\mathrm{M}$. tuberculosis growth within the granuloma requires a continuous expression of the Th1 cytokines IL-12, IFNy and TNF $\alpha$ at all times.[49], [50] and [51] If any of these cytokines are absent or blocked, TB disease reactivates. In this scenario, the continuous production of inflammatory cytokines during the chronic stage would lead to extreme inflammation-associated pathology as happens in IL-10 deficient mice 52 but for the fact that that the immune system uses the production of immunosuppressive cytokines e.g. IL-10 and TGF $\beta$ to counteract this. Thus, in chronic disease strong and sustained activation of a Th1 cytokine response against latent $M$. tuberculosis infection is responsible for the anti-microbial activity against this bacillus but this strong anti-microbial response elicited by the host is unable to completely clear the bacteria. The "halted anti-microbial capacity" of the host has two concomitant origins: first; the highly inflammatory character of the Th1 response and activation of immunosuppressive mechanisms elicited by the host to counterbalance inflammation, and second, the expression of bacterial antigens that are capable of causing immunosuppression in the host. As result of both, host inflammation and bacterial antigens, the anti-microbial activity provided by the Th1 response is intercepted and diminished [but not 
abolished]. Altogether, to survive this infection, the host must keep a tight balance between both, the Th1 response and the immunosuppressive mechanisms; otherwise it will become a diseased host. From this perspective and with the objective of enhancing/recovering the host anti-microbial activity during the latent stage of infection several strategies are being studied to modulate the lung environment including intrapulmonary delivery of cytokines [IFNY, MCSF],[10] and [53] chemokines [XCL1] $\underline{54}$ or their inhibitors [antibodies, XCL1 siRNA, TGF $\beta$ siRNA]. 55 In summary, these studies show when small concentrations of cytokines, chemokines or inhibitors of these (siRNA, antibodies, drugs) are delivered by the intrapulmonary route it is possible to change the course of the lung immune response and pathology. The main goal of these studies is to learn how and when we need to target the latently infected host to fully recover the anti-microbial activity of the infected cell and how we can use this information in the context of current chemotherapeutic treatments. With the purpose of enhancing pulmonary immunity and host anti-microbial capacity several antigen formulations and vaccines are currently being studied.[56], [57], [58], [59] and [60] These studies have benefited by recent advances in spray drying and aerosol delivery, and its application to the preparation of vaccine for inhalation.[12], [58], [59] and [61] Thus, aerosol delivery of BCG vaccine prepared as a spray-dried nanomicroparticle aerosol,[57], [58] and [59] or liposome, chitosan and PLGA-PEI DNA vaccine [56] and [62] have also been used in mice and guinea pigs to enhance pulmonary anti-microbial activity against M. tuberculosis infection. Aerosol delivery of the BCG nanomicroparticle to normal guinea pigs subsequently challenged with virulent $\mathrm{M}$. tuberculosis significantly reduced bacterial burden and lung pathology both relative to untreated animals and to control animals immunized with the standard parenteral BCG.[57] and [59] Similarly, the immunogenicity of a DNA vaccine encoding the $M$. tuberculosis latency antigen Rv1733c and the effect of pulmonary delivery and co-formulation with poly (d,I-lactide-co-glycolide) (PLGA)-polyethyleneimine (PEI) nanoparticles on host immunity is also being studied. Rv1733c DNA adsorbed to PLGA-PEI nanoparticles and applied to the lungs increased T cell proliferation and IFNY production more potently compared to the same vaccinations given intramuscularly. The strongest

immunogenicity was obtained by pulmonary priming with nanoparticle-adsorbed Rv1733c DNA followed by boosting with Rv1733c protein. These results confirm that PLGA-PEI nanoparticles are an efficient DNA vaccine delivery system to enhance $T$ cell responses through pulmonary delivery in a DNA prime/protein boost vaccine regimen. $\underline{56}$ In other studies, an HLA-A2 transgenic mouse model have been used to investigate the effects of pulmonary delivery of a new DNA plasmid encoding eight HLA-A*0201-restricted T cell epitopes from $M$. tuberculosis formulated in chitosan nanoparticles. In these studies, it was shown that the chitosan-DNA formulation was able to induce the maturation of DCs while chitosan solution alone could not, indicating the DNA was released from the particles and able to stimulate DCs. Pulmonary administration of the DNA plasmid incorporated in chitosan nanoparticles was also demonstrated to induce increased levels of IFNY secretion compared to pulmonary delivery of plasmid in solution or the more frequently used intramuscular immunization route. These results indicate that pulmonary delivery of DNA vaccines against tuberculosis may provide an advantageous delivery route compared to intramuscular immunization, and that increased immunogenicity can be achieved by delivery of this DNA encapsulated in chitosan nanoparticles. 62 Finally, a powder vaccine intended for aerosol delivery was formulated by spray drying the Adenovirus [Ad35]-vectored tuberculosis AERAS-402 vaccine with mannitolbased stabilizers and is being studied in a non-human primate animal model of TB infection. 60 These studies have demonstrated good CD4 and CD8 T cell response in the bronchoalveolar spaces.

\section{The granuloma}

There is no doubt that containment of bacillary spread coincides with granuloma formation however the number, type and size of granulomas varies even within the same patient and the 
same lung lobe 63 suggesting each granuloma is a single entity governed by its own environment. Once the granuloma is formed, this may remain as an active and well formed structure able to contain the bacilli for the rest of the patient's life, it may achieve localized sterilization of the infection and mineralization of the lesion or, in the worst case scenario, it may progress into a localized caseation and necrosis that eventually will break down and release the bacteria into the airways.

The complexity of pulmonary macrophage cell populations during a chronic M. tuberculosis infection reach its climax at the granuloma level. At this location, these cells can be found as monocytes, macrophages, dendritic cell[45] and [64] multinucleated cells giant cells, epitheloid cells and foamy cells.[45], [63], [65] and [66] As the granuloma matures, many macrophages cells within the granuloma engulf large quantities' of lipids, [63], [66], [67], [68], [69]and [70] express high levels of intracellular immunosuppressive and pro fibrotic cytokines IL-10, IL-4, TGF $\beta$ and anti-apoptotic markers

[TRAF].[45] and [64]These cells are eventually driven into the core of the granuloma protected/strangled [depending on the outcome of disease] by a fibrotic envelope that excludes the $\mathrm{T}$ cells [source of IFNy and responsible for anti-microbial activation] and large numbers of B cells [of unknown function]. During this process the center of the granuloma progressively becomes very hypoxic in nature[71] and [72] and the predominant macrophage phenotype in the core of the granuloma becomes the multinucleated and foamy cell also expressing immunosuppressive cytokines IL-10 and IL-4 but not TGF $\beta$ [mouse model Gonzalez-Juarrero unpublished data]. In humans, non-human primates and guinea pigs the center of the granuloma may progress into a caseum and necrotic lesion that eventually collapses and fails to retain the infectious bacilli.[63], [73] and [74]

Lipids within the granuloma and foamy cells appear to be of both host and bacterial origin. [63], [67] and [68] In humans the developmental process leading to caseation at the core of the granuloma appears to be correlated with the content and accumulation of lipids. $\underline{68}$ Russell's group exploited genome-wide microarray analysis to show that within the caseous granuloma there is sequestration of low density lipids droplets and high levels of ceramides which influences cell morphology (foamy cell appearance), cholesterol sequestration and cell death.

\section{Role of mycobacterial antigens in persistence of M. tuberculosis}

The role of mycobacterial mannosylated lipids as a potential factor involved in persistence of $M$. tuberculosis within infected cells have been supported by multiple studies.[4], [75], [76], [77], [78] and [79] Bloom's group in $1991 \underline{80}$ reported a potential role for lipoarabinomannans [LAM] as factors in the persistence of M. tuberculosis in infected cells, and other studies also attributed this capacity specifically to manLAM. [81] and [82] Most recently, Schlesinger and Torrelles have demonstrated that $M$. tuberculosis clinical isolates vary in their degree of surface mannosylation and they suggest these differences may have great impact on the outcome of the disease. 78 There is direct evidence manLAM affects DC maturation and function[79], [83] and [84] and the same antigen either as a cell wall component of $M$.

tuberculosis or as a free antigen, drives DCs into IL-10

production. [76], [85], [86], [87], [88] and [89] Thus, mycobacterial mannosylated lipids are believed to play an important role in bacterial persistence by modulating the host response during the course of chronic infection with $\mathrm{M}$. tuberculosis. $\underline{90}$ Several groups have demonstrated that manLAM binds to the mannose receptor [MR], and the dendritic cell-specific intercellular adhesion molecule-3 grabbing nonintegrin [DC-SIGN] molecule present on the surface of AM and DCs.[88], [89], [90] and [91]Schlesinger's group demonstrated that binding 
of ManLAM to MR or DC-SIGN molecules activates different pathways of phagosomal traffic. 76 Other mycobacterial antigens may act in a similar manner; for instance, $M$. tuberculosis secretory antigen (MTSA)-differentiated DCs and MTSA-matured DCs were shown to down-regulate inflammatory responses of M. tuberculosis primed T cells. 92 This collectively demonstrates that mycobacterial lipids can accumulate in the granuloma, down-regulate protective immune responses to the bacillus, and lower anti-microbial expression by stimulating immunosuppressive mechanisms and/or alternative pathways of cell activation in $\mathrm{AM}$ and DCs.

\section{The role of cell death in the immune response to $M$. tuberculosis}

M. tuberculosis is an intracellular pathogen and its survival within the host requires living cells. Cell suicide is an important innate defence against intracellular pathogens. Host cell death not only inhibits bacterial replication by depriving the pathogen of its niche but also stimulates innate and adaptive immune responses; the latter vary depending on the mechanism of cell death; apoptosis or necrosis. Until recently, apoptosis (characterized by the activation of caspases and the formation of apoptotic bodies which are phagocytosed before the loss of membrane integrity) was deemed to be immunologically silent. On the contrary, necrosis was thought to be an accidental event resulting in rapid cell lysis and inflammation. It is now known however, that apoptosis can be either tolerogenic or immunogenic depending on the context in which it occurs.93 Thus, during development or maintenance of homeostasis the interaction of apoptotic cells with dendritic cells results in the proliferation of regulatory $T$ cells 94 and when apoptosis is accompanied by expression of damage-associated molecules such as calreticulin, 93 or occurs in the context of a bacterial infection with exposure of pathogen-associated molecules, interacting dendritic cells can stimulate protective immune responses. 94 Conversely, necrosis can occur in a highly regulated fashion and does not necessarily evoke an immunogenic reaction in responding cells.

Several lines of evidence suggest that macrophage apoptosis is beneficial for the host response to tuberculosis by having direct bactericidal effects on intracellular mycobacteria and also in the stimulation of protective immunity. For example, the induction of apoptosis of cultured macrophages by exogenous apoptotic stimuli such as Fas ligand reduces the survival of intracellular M. tuberculosis 95 whereas necrosis does not prevent bacillary growth. In addition, macrophages from an inbred strain of mouse $(\mathrm{C} 3 \mathrm{HeB} / \mathrm{FeJ})$ that is susceptible to $\mathrm{M}$. tuberculosis infection undergo necrosis when infected while macrophages from the less susceptible strains of mice undergo apoptosis. 96 Furthermore, apoptotic vesicles released by dying, infected macrophages are taken up by dendritic cells and cross prime CD8+ T cells via MHC1 and CD1 molecules.[97] and [98] The resulting antigen-specific cytotoxic T cells can then kill infected macrophages via the perforin-granzyme pathway.

In its battle to survive within the host it appears that M. tuberculosis can also inhibit host cell death or manipulate the mechanism of death. Indeed, it has been suggested that virulent strains of mycobacteria inhibit macrophage apoptosis[99], [100], [101] and [102] but cause necrosis and that this promotes the survival of M. tuberculosis. This is supported by recent data indicating that the genome of $\mathrm{M}$. tuberculosis encodes for genes that actively inhibit macrophage apoptosis and enhance intracellular survival, including nuoG, 103 pknE 104 and secA. 105 Deletion mutants of some of these genes have been found to induce more apoptosis than the wild type bacilli. In fact, the secA deletion mutant, which is attenuated in mice, stimulates a more robust pathogen-specific CD8+ T cell response. 106 
Despite its ability to (at least partially) inhibit apoptosis there is no doubt that $\mathrm{M}$. tuberculosis causes macrophage cell death both in vivo and in vitroalthough the mechanism is not fully understood. 107 The effect that M. tuberculosis and its components exert on macrophage viability appears to be multifaceted. TNF, released by macrophages infected with M. tuberculosis, can signal in an autocrine fashion to cause cell death. It has been reported that TNF-mediated apoptosis of infected murine macrophages is dependent on the MAP kinases p38 and ASK1; p38 phosphorylates the anti-apoptotic protein FLIP which is also phosphorylated by $\mathrm{c}-\mathrm{ABL}$, tagging it for degradation by the proteasome and thus allowing autoactivation of procaspase 8 and apoptosis. 108 However, there is also evidence that M. tuberculosis can inhibit the extrinsic[109] and [110] and intrinsic pathways of apoptosis in vitro[111] and[112] by interfering with TNF signalling and upregulating anti-apoptotic host cell mediators such as $\mathrm{Mcl}-1$ and $\mathrm{A} 1$. In addition, foamy macrophages in granulomas in the lungs of mice infected with $M$. tuberculosis have been found to express high levels of TNFRassociated factors (TRAFS) 1-3 which are associated with resistance to apoptosis. 45 In keeping with these data human and murine macrophages have been reported to undergo TNF- and caspase-independent cell death which is associated with activation of cathepsin and serine proteases.[113] and [114] Given the influence that cell death has in shaping the immune response to $M$. tuberculosis infection and the ability of the pathogen to subvert this process, it is not surprising that infected macrophages might activate multiple redundant cell death pathways. Inhaled therapies that stimulate caspase activity in infected macrophages and drive the cell death mechanism towards apoptosis rather than necrosis could be beneficial in the treatment of tuberculosis.[115] and [116] Understanding the precise cell death mechanism(s) induced by $M$. tuberculosis in macrophages and the subsequent consequences for the innate and adaptive immune response may aid in the development of new therapies and vaccines for tuberculosis.

In summary, the outcome of an infection with $M$. tuberculosis is determined by the balance between a series of host- and pathogen-driven events. The host attempts to eliminate or contain the infection within the granuloma by inducing macrophage apoptosis, activation of macrophages, maturation and migration of dendritic cells and the stimulation of a protective Th1 adaptive immune response. On the other hand, the pathogen seeks to subvert this host response by strategies such as inhibiting apoptosis, inhibiting lysosome maturation and hijacking host cell lipid metabolism to survive the hostile environment of the phagosome and promoting a regulatory $T$ cell response. In addition, the immunosuppressive environment of the alveolus aids the pathogen in its task, in the early and late stages of infection. In the design of effective inhaled drug delivery systems to treat or prevent $M$. tuberculosisinfection the complex interplay between all of these elements will need to be taken into consideration.

\section{Funding}

MO'S is supported by funding from Science Foundation Ireland (SFI) and the Health Research Board (HRB).

\section{Competing interests}

None declared.

\section{Ethical approval Not required.}


1 B.C. Trapnell and J.A. Whitsett, GM-CSF regulates pulmonary surfactant homeostasis and alvoelar macrophage-mediated innate host defense, Annu Rev Physiol 64 (2002), pp. 775802. Full Text via CrossRef I View Record in Scopus | Cited By in Scopus (83)

2 J.S. Ferguson and L.S. Schlesinger, Pulmonary surfactant in innate immunity and the pathogenesis of tuberculosis, Tuber Lung Dis 80 (2000), pp. 173-184. Abstract I PDF (399 K) I View Record in Scopus | Cited By in Scopus (14)

$\underline{3}$ Y. Shibata, P.Y. Berclaz, Z.C. Chroneos, M. Yoshida, J.A. Whitsett and B.C. Trapnell, GM-CSF regulates alveolar macrophage differentiation and innate immunity in the lung through PU.1, Immunity 15 (2001), pp. 557-567. Article I PDF (461 K) | View Record in Scopus | Cited By in Scopus (140)

4 J.B. Torrelles, A.K. Azad, L.N. Henning, T.K. Carlson and L.S. Schlesinger, Role of C-type lectins in mycobacterial infections, Curr Drug Targets 9(2008), pp. 102-112. View Record in Scopus I Cited By in Scopus (16)

$\underline{5}$ T. Bernier, T. Tschernig, R. Pabst, O. Macke, C. Steinmueller and A. Emmendorffer, Effects of macrophage-CSF on pulmonary-macrophage repopulation after bone marrow transplantation, J Leukoc Biol 70 (2001), pp. 39-45. View Record in Scopus I Cited By in Scopus (5)

6 B.J. Masten, G.K. Olson, D.F. Kusewitt and M.F. Lipscomb, Flt3 ligand preferentially increases the number of functionally active myeloid dendritic cells in the lungs of mice, J Immunol 172 (2004), pp. 4077-4083. View Record in Scopus I Cited By in Scopus (25)

$\underline{7}$ M. Gonzalez-Juarrero, T.S. Shim, A. Kipnis, A.P. Junqueira-Kipnis and I.M. Orme, Dynamics of macrophage cell populations during murine pulmonary tuberculosis, J Immunol 171 (2003), pp. 3128-3135. View Record in Scopus | Cited By in Scopus (80)

$\underline{8}$ K. Vermaelen and R. Pauwels, Pulmonary dendritic cells, Am J Respir Crit Care Med 172 (2005), pp. 530-551. Full Text via CrossRef I View Record in Scopus | Cited By in Scopus (91)

9 C. Jakubzick, F. Tacke, J. Llodra, N. van Rooijen and G.J. Randolph, Modulation of dendritic cell trafficking to and from the airways, J Immunol 176(2006), pp. 3578-3584. View Record in Scopus | Cited By in Scopus (66)

10 D.M. Higgins, J. Sanchez-Campillo, A.G. Rosas-Taraco, J.R. Higgins, E.J. Lee and I.M. Orme et al., Relative levels of M-CSFand GM-CSF influence the specific generation of macrophage populations during infection with Mycobacterium tuberculosis, J Immunol 180 (2008), pp. 4892-4900. View Record in Scopus I Cited By in Scopus (3)

11 P.A. Stumbles, J.W. Upham and P.G. Holt, Airway dendritic cells: co-ordinators of immunological homeostasis and immunity in the respiratory tract,APMIS 111 (2003), pp. 741755. Full Text via CrossRef I View Record in Scopus I Cited By in Scopus (39)

12 P. Muttil, C. Wang and A.J. Hickey, Inhaled drug delivery for tuberculosis therapy, Pharm Res 26 (2009), pp. 2401-2416. Full Text via CrossRef I View Record in Scopus I Cited By in Scopus (4)

13 P. Muttil, J. Kaur, K. Kumar, A.B. Yadav, R. Sharma and A. Misra, Inhalable microparticles containing large payload of anti-tuberculosis drugs, Eur J Pharm Sci 32 (2007), pp. 140150. Article | PDF (649 K) | View Record in Scopus | Cited By in Scopus (11) 
14 , The pathogenesis of tuberculosis v ( 2 nd ed.), Charles C. Thomas, Springfield, Illinios (1951).

15 L.S. Schlesinger, Role of mononuclear phagocytes in M. tuberculosis pathogenesis, J Investig Med 44 (1996), pp. 312-323. View Record in Scopus ICited By in Scopus (23)

16 L.S. Schlesinger, Entry of Mycobacterium tuberculosis into mononuclear phagocytes, Curr Top Microbiol Immunol 215 (1996), pp. 71-96. View Record in Scopus | Cited By in Scopus (30)

17 T.K. Carlson, J.B. Torrelles, K. Smith, T. Horlacher, R. Castelli and P.H. Seeberger et al., Critical role of amino acid position 343 of surfactant protein-D in the selective binding of glycolipids from mycobacterium tuberculosis, Glycobiology 19 (2009), pp. 1473-1484. Full Text via CrossRef I View Record in Scopus I Cited By in Scopus (1)

18 J.S. Ferguson et al., Surfactant protein D increases fusion of Mycobacterium tuberculosiscontaining phagosomes with lysosomes in human macrophages, Infect Immun 74 (2006), pp. 7005-7009. Full Text via CrossRef I View Record in Scopus I Cited By in Scopus (14)

19 J.S. Ferguson, D.R. Voelker, J.A. Ufnar, A.J. Dawson and L.S. Schlesinger, Surfactant protein d inhibition of human macrophage uptake ofMycobacterium tuberculosis is independent of bacterial agglutination, J Immunol 168 (2002), pp. 1309-1314. View Record in Scopus I Cited By in Scopus (44)

20 C.D. Gaynor, F.X. McCormack, D.R. Voelker, S.E. McGowan and L.S. Schlesinger, Pulmonary surfactant protein a mediates enhanced phagocytosis ofMycobacterium tuberculosis by a direct interaction with human macrophages, J Immunol 155 (1995), pp. 5343-5351. View Record in Scopus I Cited By in Scopus (161)

$\underline{21}$ L. Hall-Stoodley, G. Watts, J.E. Crowther, A. Balagopal, J.B. Torrelles and J. Robison-Cox et al., Mycobacterium tuberculosis binding to human surfactant proteins a and d, fibronectin, and small airway epithelial cells under shear conditions, Infect Immun 74 (2006), pp. 35873596. Full Text via CrossRef I View Record in Scopus I Cited By in Scopus (9)

22 U. Schwab, K.H. Rohde, Z. Wang, P.R. Chess, R.H. Notter and D.G. Russell, Transcriptional responses of Mycobacterium tuberculosis to lung surfactant, Microb Pathog 46 (2009), pp. 185-193. Article I PDF (491 K) I View Record in Scopus I Cited By in Scopus (5)

23 Z. Wang, U. Schwab, E. Rhoades, P.R. Chess, D.G. Russell and R.H. Notter, Peripheral cell wall lipids of Mycobacterium tuberculosis are inhibitory to surfactant function, Tuberculosis (Edinb) 88 (2008), pp. 178-186. Article I PDF (405 K) I View Record in Scopus I Cited By in Scopus (5)

24 J. Day, A. Friedman and L.S. Schlesinger, Modeling the immune rheostat of macrophages in the lung in response to infection, Proc Natl Acad Sci U S A 106 (2009), pp. 11246-11251. Full Text via CrossRef I View Record in Scopus | Cited By in Scopus (7)

25 A.B. Yadav, R. Sharma, P. Muttil, A.K. Singh, R.K. Verma and M. Mohan et al., Inhalable microparticles containing isoniazid and rifabutin target macrophages and 'stimulate the phagocyte' to achieve high efficacy, Indian J Exp Biol 47 (2009), pp. 469-474. View Record in Scopus | Cited By in Scopus (0)

26 R. Sharma, D. Saxena, A.K. Dwivedi and A. Misra, Inhalable microparticles containing drug combinations to target alveolar macrophages for treatment of pulmonary tuberculosis, Pharm Res 18 (2001), pp. 1405-1410. Full Text via CrossRef I View Record in Scopus I Cited By in Scopus (57) 
27 I.M. Orme and A.M. Cooper, Cytokine/chemokine cascades in immunity to tuberculosis, Immunol Today 20 (1999), pp. 307-312. Abstract I PDF (221 K) I View Record in Scopus | Cited By in Scopus (148)

28 I.M. Orme, E.S. Miller, A.D. Roberts, S.K. Furney, J.P. Griffin and K.M. Dobos et al., T lymphocytes mediating protection and cellular cytolysis during the course of mycobacterium tuberculosis infection. Evidence for different kinetics and recognition of a wide spectrum of protein antigens, J Immunol 148(1992), pp. 189-196. View Record in Scopus I Cited By in Scopus (157)

29 I.M. Orme, A.D. Roberts, J.P. Griffin and J.S. Abrams, Cytokine secretion by CD4 T lymphocytes acquired in response to Mycobacterium tuberculosisinfection, J Immunol 151 (1993), pp. 518-525. View Record in Scopus I Cited By in $\underline{\text { Scopus (231) }}$

30 A.M. Caruso, N. Serbina, E. Klein, K. Triebold, B.R. Bloom and J.L. Flynn, Mice deficient in CD4 T cells have only transiently diminished levels of IFN-gamma, yet succumb to tuberculosis, J Immunol 162 (1999), pp. 5407-5416. View Record in Scopus I Cited By in Scopus (208)

$\underline{31}$ J.L. Flynn, M.M. Goldstein, K.J. Triebold, B. Koller and B.R. Bloom, Major histocompatibility complex class I-restricted $T$ cells are required for resistance to Mycobacterium tuberculosis infection, Proc Natl Acad Sci U S A 89 (1992), pp. 12013-12017. Full Text via CrossRef I View Record in Scopus I Cited By in Scopus (443)

32 N.V. Serbina and J.L. Flynn, Early emergence of CD8(+) T cells primed for production of type 1 cytokines in the lungs of Mycobacterium tuberculosis-infected mice, Infect Immun 67 (1999), pp. 3980-3988. View Record in Scopus I Cited By in Scopus (110)

$33 \mathrm{~J}$. Turner and I.M. Orme, Identification of altered integrin alpha/beta chain expression on T cells from old mice infected with Mycobacterium tuberculosis, Exp Gerontol 37 (2002), pp. 907-916. Article I PDF (232 K) | View Record in Scopus | Cited By in Scopus (5)

34 W.H. Boom, K.A. Chervenak, M.A. Mincek and J.J. Ellner, Role of the mononuclear phagocyte as an antigen-presenting cell for human gamma delta $T$ cells activated by live Mycobacterium tuberculosis, Infect Immun 60 (1992), pp. 3480-3488. View Record in Scopus I Cited By in Scopus (68)

35 C.D. D'Souza et al., An anti-inflammatory role for gamma delta T lymphocytes in acquired immunity to Mycobacterium tuberculosis, J Immunol 158(1997), pp. 1217-1221.

36 A.P. Junqueira-Kipnis, A. Kipnis, A. Jamieson, M.G. Juarrero, A. Diefenbach and D.H. Raulet et al., NK cells respond to pulmonary infection withMycobacterium tuberculosis, but play a minimal role in protection, J Immunol 171 (2003), pp. 6039-6045. View Record in Scopus | Cited By in Scopus (47)

37 A.M. Cooper, J. Magram, J. Ferrante and I.M. Orme, Mice lacking bioactive IL-12 can generate protective, antigen-speciifc cellular responses to mycobacterial infection only if the IL-12 p40 subunit is present, J Immunol 186 (2002), pp. 1322-1327. View Record in Scopus I Cited By in Scopus (179)

38 A.M. Cooper, J. Magram, J. Ferrante and I.M. Orme, IL-12 is crucial to the development of protective immunity in mice intravenously infected withMycobacterium tuberculosis, J Exp Med 186 (1997), pp. 39-46.

39 A.M. Cooper and J.L. Flynn, The protective immune response to Mycobacterium 
tuberculosis, Curr Opin Immunol 7 (1995), pp. 512-516. Article I PDF (546 K) I View Record in Scopus I Cited By in Scopus (120)

40 S.A. Khader, G.K. Bell, J.E. Pearl, J.J. Fountain, J. Rangel-Moreno and G.E. Cilley et al., IL-23 and IL-17 in the establishment of protective pulmonary CD4+ T cell responses after vaccination and during Mycobacterium tuberculosis challenge, Nat Immunol 8 (2007), pp. 369377. Full Text via CrossRef IView Record in Scopus I Cited By in Scopus (262)

41 S.A. Khader et al., IL-23 compensates for the absence of IL-12p70 and is essential for the IL-17 response during tuberculosis but is dispensable for protection and antigen-specific IFN\{gamma\} responses if IL-12p70 is available, J Immunol 175 (2005), pp. 788-795. View Record in Scopus | Cited By in Scopus (148)

42 S.A. Khader, J.E. Pearl, K. Sakamoto, L. Gilmartin, G.K. Bell and D.M. Jelley-Gibbs et al., Tumor necrosis factor-alpha is required in the protective immune response against Mycobacterium tuberculosis in mice, Immunity 2 (1995), pp. 561-572.

43 I.R. Humphreys, G.R. Stewart, D.J. Turner, J. Patel, D. Karamanou and R.J. Snelgrove et al., A role for dendritic cells in the dissemination of mycobacterial infection, Microbes Infect 8 (2006), pp. 1339-1346. Article I PDF (402 K) I View Record in Scopus I Cited By in Scopus (27)

44 A.M. Cooper, Cell-mediated immune responses in tuberculosis, Annu Rev Immunol 27 (2009), pp. 393-422. Full Text via CrossRef I View Record in Scopus I Cited By in Scopus (39)

45 D. Ordway, M. Henao-Tamayo, I.M. Orme and M. Gonzalez-Juarrero, Foamy macrophages within lung granulomas of mice infected withMycobacterium tuberculosis express molecules characteristic of dendritic cells and antiapoptotic markers of the TNFreceptor-associated factor family, J Immunol 175 (2005), pp. 3873-3881. View Record in Scopus I Cited By in Scopus (32)

46 M. Gonzalez-Juarrero and I.M. Orme, Characterization of murine lung dendritic cells infected with Mycobacterium tuberculosis, Infect Immun 69(2001), pp. 1127-1133. Full Text via CrossRef I View Record in Scopus I Cited By in Scopus (85)

47 J. Turner, A.A. Frank, J.V. Brooks, M. Gonzalez-Juarrero and I.M. Orme, The progression of chronic tuberculosis in the mouse does not require the participation of $B$ lymphocytes or interleukin-4, Exp Gerontol 36 (2001), pp. 537-545. Article I PDF (447 K) I View Record in Scopus | Cited By in Scopus (26)

48 M. Gonzalez-Juarrero, L.C. Kingry, D.J. Ordway, M. Henao-Tamayo, M. Harton and R.J. Basaraba et al., Immune response to mycobacterium tuberculosis and identification of molecular markers of disease, Am J Respir Cell Mol Biol 40 (2009), pp. 398-409. View Record in Scopus | Cited By in Scopus (3)

49 V.P. Mohan, C.A. Scanga, K. Yu, H.M. Scott, K.E. Tanaka and E. Tsang et al., Effects of tumor necrosis factor alpha on host immune response in chronic persistent tuberculosis: possible role for limiting pathology, Infect Immun 69 (2001), pp. 1847-1855. Full Text via CrossRef I View Record in Scopus I Cited By in Scopus (230)

50 M.P. Moiton, C. Richez, C. Dumoulin, N. Mehsen, J. Dehais and T. Schaeverbeke, Role of anti-tumour necrosis factor-alpha therapeutic agents in the emergence of infections, Clin Microbiol Infect 12 (2006), pp. 1151-1153. Full Text via CrossRef I View Record in Scopus | Cited By in Scopus (14)

51 J. Keane, S. Gershon, R.P. Wise, E. Mirabile-Levens, J. Kasznica and W.D. Schwieterman et al., Tuberculosis associated with infliximab, a tumor necrosis factor alpha-neutralizing 
agent, N Engl J Med 345 (2001), pp. 1098-1104. Full Text via CrossRef I View Record in Scopus | Cited By in Scopus (1647)

52 D.M. Higgins, J. Sanchez-Campillo, A.G. Rosas-Taraco, E.J. Lee, I.M. Orme and M. Gonzalez-Juarrero, Lack of IL-10 alters inflammatory and immune responses during pulmonary Mycobacterium tuberculosis infection, Tuberculosis (Edinb) 89 (2009), pp. 149157. Article | PDF (3513 K) | View Record in Scopus | Cited By in Scopus (5)

53 E.F. Redente, D.M. Higgins, L.D. Dwyer-Nield, I.M. Orme, M. Gonzalez-Juarrero and A.M. Malkinson, Differential polarization of alveolar macrophages and bone marrow-derived monocytes following chemically and pathogen-induced chronic lung inflammation, J Leukoc Biol 88 (2010), pp. 159-168. Full Text via CrossRef I View Record in Scopus | Cited By in Scopus (0)

54 D. Ordway, D.M. Higgins, J. Sanchez-Campillo, J.S. Spencer, M. Henao-Tamayo and M. Harton et al., XCL1 (lymphotactin) chemokine produced by activated CD8 T cells during the chronic stage of infection with Mycobacterium tuberculosis negatively affects production of IFN-gamma by CD4 T cells and participates in granuloma stability, J Leukoc Biol 82 (2007), pp. 1221-1229. Full Text via CrossRef I View Record in Scopus I Cited By in Scopus (11)

55 A.G. Rosas-Taraco, D.M. Higgins, J. Sanchez-Campillo, E.J. Lee, I.M. Orme and M.I. Gonzalez-Juarrero, Intrapulmonary delivery of XCL1-targeting small interfering RNA in mice chronically infected with Mycobacterium tuberculosis, Am J Respir Cell Mol Biol 41 (2009), pp. 136-145. Full Text via CrossRef I View Record in Scopus | Cited By in Scopus (1)

$\underline{56}$ M. Bivas-Benita, M.Y. Lin, S.M. Bal, K.E. van Meijgaarden, K.L. Franken and A.H. Friggen et al., Pulmonary delivery of DNA encoding Mycobacterium tuberculosis latency antigen Rv1733c associated to PLGA-PEI nanoparticles enhances T cell responses in a DNA prime/protein boost vaccination regimen in mice, Vaccine 27 (2009), pp. 4010-4017. Article I PDF (566 K) I View Record in Scopus I Cited By in Scopus (2)

57 P.B. Fourie, W.A. Germishuizen, Y.L. Wong and D.A. Edwards, Spray drying TB vaccines for pulmonary administration, Expert Opin Biol Ther 8 (2008), pp. 857-863. Full Text via CrossRef I View Record in Scopus | Cited By in Scopus (2)

58 L. Garcia-Contreras, J. Fiegel, M.J. Telko, K. Elbert, A. Hawi and M. Thomas et al., Inhaled large porous particles of capreomycin for treatment of tuberculosis in a guinea pig model, Antimicrob Agents Chemother 51 (2007), pp. 2830-2836. Full Text via CrossRef I View Record in Scopus | Cited By in Scopus (17)

59 L. Garcia-Contreras, Y.-L. Wong, P. Muttil, D. Padilla, J. Sadoff and J. DeRousse et al., Immunization by a bacterial aerosol, Proc Natl Acad Sci U S A105 (2008), pp. 4656-4660. Full Text via CrossRef I View Record in Scopus | Cited By in Scopus (17)

$\underline{60}$ T.H. Jin, E. Tsao, J. Goudsmit, V. Dheenadhayalan and J. Sadoff, Stabilizing formulations for inhalable powders of an adenovirus 35 -vectored tuberculosis (TB) vaccine (AERAS402), Vaccine 28 (2010), pp. 4369-4375. Article I PDF (899 K) I View Record in Scopus I Cited By in Scopus (0)

$61 \mathrm{C}$. Wang and A. Hickey, Isoxyl aerosols for tuberculosis treatment: preparation and characterization of particles, AAPS PharmSciTech 11 (2010), pp. 538-549. Full Text via CrossRef I View Record in Scopus | Cited By in Scopus (1)

62 M. Bivas-Benita, K.E. van Meijgaarden, K.L.M.C. Franken, H.E. Junginger, G. Borchard and T.H.M. Ottenhoff et al., Pulmonary delivery of chitosan-DNA nanoparticles enhances the immunogenicity of a DNA vaccine encoding hla-a*0201-restricted T-cell epitopes 
of Mycobacterium tuberculosis, Vaccine 22 (2004), pp. 1609-1615. Article I PDF (117 K) I View Record in Scopus I Cited By in Scopus (55)

63 D.G. Russell, P.-J. Cardona, M.-J. Kim, S. Allain and F. Altare, Foamy macrophages and the progression of the human tuberculosis granuloma, Nat Immunol 10 (2009), pp. 943-948. Full Text via CrossRef I View Record in Scopus I Cited By in Scopus (8)

64 D. Ordway, M. Harton, M. Henao-Tamayo, R. Montoya, I.M. Orme and M. Gonzalez-Juarrero, Enhanced macrophage activity in granulomatous lesions of immune mice challenged with Mycobacterium tuberculosis, J Immunol 176 (2006), pp. 4931-4939. View Record in Scopus | Cited By in Scopus (15)

65 N. Cáceres, G. Tapia, I. Ojanguren, F. Altare, O. Gil and S. Pinto et al., Evolution of foamy macrophages in the pulmonary granulomas of experimental tuberculosis models, Tuberculosis 89 (2009), pp. 175-182. Article I PDF (4388 K) I View Record in Scopus | Cited By in Scopus (6)

66 P. Peyron, J. Vaubourgeix, Y. Poquet, F. Levillain, C. Botanch and F. Bardou et al., Foamy macrophages from tuberculous patients' granulomas constitute a nutrient-rich reservoir for $M$. Tuberculosis persistence, PLoS Pathog 4 (2008), p. e1000204. Full Text via CrossRef I View Record in Scopus ICited By in Scopus (17)

67 D.G. Russell, Who puts the tubercle in tuberculosis?, Nat Rev Microbiol 5 (2007), pp. 3947. Full Text via CrossRef I View Record in Scopus I Cited By in Scopus (91)

68 M.J. Kim, H.C. Wainwright, M. Locketz, L.G. Bekker, G.B. Walther and C. Dittrich et al., Caseation of human tuberculosis granulomas correlates with elevated host lipid metabolism, EMBO Mol Med (2010).

69 E.R. Rhoades, R.E. Geisel, B.A. Butcher, S. McDonough and D.G. Russell, Cell wall lipids from Mycobacterium bovis BCG are inflammatory when inoculated within a gel matrix: characterization of a new model of the granulomatous response to mycobacterial components, Tuberculosis (Edinb) 85(2005), pp. 159-176. Article I PDF (921 K) I View Record in Scopus | Cited By in Scopus (9)

$\underline{70}$ H. Takimoto, H. Maruyama, K.I. Shimada, R. Yakabe, I. Yano and Y. Kumazawa, Interferongamma independent formation of pulmonary granuloma in mice by injections with trehalose dimycolate (cord factor), lipoarabinomannan and phosphatidylinositol mannosides isolated from Mycobacterium tuberculosis, Clin Exp Immunol 144 (2006), pp. 134-141. Full Text via CrossRef I View Record in Scopus | Cited By in Scopus (3)

71 L.E. Via, P.L. Lin, S.M. Ray, J. Carrillo, S.S. Allen and S.Y. Eum et al., Tuberculous granulomas are hypoxic in guinea pigs, rabbits, and nonhuman primates, Infect Immun 76 (2008), pp. 2333-2340. Full Text via CrossRef I View Record in Scopus | Cited By in Scopus (38)

72 M.C. Tsai, S. Chakravarty, G. Zhu, J. Xu, K. Tanaka and C. Koch et al., Characterization of the tuberculous granuloma in murine and human lungs: cellular composition and relative tissue oxygen tension, Cell Microbiol 8 (2006), pp. 218-232. Full Text via CrossRef I View Record in Scopus I Cited By in Scopus (70)

73 J.L. Flynn, S.V. Capuano, D. Croix, S. Pawar, A. Myers and A. Zinovik et al., Non-human primates: a model for tuberculosis research, Tuberculosis (Edinb) 83 (2003), pp. 116118. Article I PDF (56 K) | View Record in Scopus I Cited By in Scopus (26)

74 R.J. Basaraba, E.E. Smith, C.A. Shanley and I.M. Orme, Pulmonary lymphatics are primary sites of Mycobacterium tuberculosis infection in guinea pigs infected by aerosol, Infect 
Immun 74 (2006), pp. 5397-5401. Full Text via CrossRef I View Record in Scopus I Cited By in Scopus (15)

75 L.S. Schlesinger, T.M. Kaufman, S. Iyer, S.R. Hull and L.K. Marchiando, Differences in mannose receptor-mediated uptake of lipoarabinomannan from virulent and attenuated strains of Mycobacterium tuberculosis by human macrophages, J Immunol 157 (1996), pp. 45684575. View Record in Scopus ICited By in Scopus (84)

76 J.B. Torrelles, A.K. Azad and L.S. Schlesinger, Fine discrimination in the recognition of individual species of phosphatidyl-myo-inositol mannosides from Mycobacterium tuberculosis by C-type lectin pattern recognition receptors, J Immunol 177 (2006), pp. 18051816. View Record in Scopus I Cited By in Scopus (34)

77 J.B. Torrelles, L.E. DesJardin, J. MacNeil, T.M. Kaufman, B. Kutzbach and R. Knaup et al., Inactivation of Mycobacterium tuberculosismannosyltransferase PIMb reduces the cell wall lipoarabinomannan and lipomannan content and increases the rate of bacterial-induced human macrophage cell death, Glycobiology 19 (2009), pp. 743-755. Full Text via CrossRef I View Record in Scopus I Cited By in Scopus (7)

78 J.B. Torrelles and L.S. Schlesinger, Diversity in Mycobacterium tuberculosis mannosylated cell wall determinants impacts adaptation to the host,Tuberculosis (Edinb) 90 (2010), pp. 8493. Article I PDF (727 K) | View Record in Scopus | Cited By in Scopus (0)

79 J. Nigou, C. Zelle-Rieser, M. Gilleron, M. Thurnher and G. Puzo, Mannosylated lipoarabinomannans inhibit IL-12 production by human dendritic cells: evidence for a negative signal delivered through the mannose receptor, J Immunol 166 (2001), pp. 7477-7485. View Record in Scopus I Cited By in Scopus (194)

$\underline{80}$ J. Chan, X.D. Fan, S.W. Hunter, P.J. Brennan and B.R. Bloom, Lipoarabinomannan, a possible virulence factor involved in persistence ofMycobacterium tuberculosis within macrophages, Infect Immun 59 (1991), pp. 1755-1761. View Record in Scopus | Cited By in $\underline{\text { Scopus (181) }}$

$\underline{81}$ K.E. Dahl, H. Shiratsuchi, B.D. Hamilton, J.J. Ellner and Z. Toossi, Selective induction of transforming growth factor beta in human monocytes by lipoarabinomannan of Mycobacterium tuberculosis, Infect Immun 64 (1996), pp. 399-405. View Record in Scopus I Cited By in Scopus (107)

$\underline{82}$ M. Rojas, L.F. Barrera, G. Puzo and L.F. Garcia, Differential induction of apoptosis by virulent Mycobacterium tuberculosis in resistant and susceptible murine macrophages: role of nitric oxide and mycobacterial products, J Immunol 159 (1997), pp. 1352-1361. View Record in Scopus I Cited By in Scopus (112)

$\underline{83}$ J. Nigou, M. Gilleron, M. Rojas, L.F. Garcia, M. Thurnher and G. Puzo, Mycobacterial lipoarabinomannans: modulators of dendritic cell function and the apoptotic response, Microbes Infect 4 (2002), pp. 945-953. View Record in Scopus | Cited By in Scopus (74)

$\underline{84}$ N. Dulphy, J.L. Herrmann, J. Nigou, D. Rea, N. Boissel and G. Puzo et al., Intermediate maturation of Mycobacterium tuberculosis LAM-activated human dendritic cells, Cell Microbiol 9 (2007), pp. 1412-1425. Full Text via CrossRef I View Record in Scopus I Cited By in Scopus (7)

85 V. Briken, S.A. Porcelli, G.S. Besra and L. Kremer, Mycobacterial lipoarabinomannan and related lipoglycans: from biogenesis to modulation of the immune response, Mol Microbiol 53 (2004), pp. 391-403. Full Text via CrossRef I View Record in Scopus I Cited By in 
$\underline{86}$ W.L. Beatty, E.R. Rhoades, H-J. Ullrich, D. Chatterjee, J.E. Heuser and D.G. Russell, Trafficking and release of mycobacterial lipids from infected macrophages, Traffic 1 (2000), pp. 235-247. Full Text via CrossRef I View Record in Scopus I Cited By in Scopus (166)

$\underline{87}$ S. Xu, A. Cooper, S. Sturgill-Koszycki, T. van Heyningen, D. Chatterjee and I. Orme et al., Intracellular trafficking in Mycobacterium tuberculosis andMycobacterium avium-infected macrophages, J Immunol 153 (1994), pp. 2568-2578. View Record in Scopus I Cited By in $\underline{\text { Scopus (237) }}$

$\underline{88}$ T.B. Geijtenbeek, S.J. Van Vliet, E.A. Koppel, M. Sanchez-Hernandez, C.M. VandenbrouckeGrauls and B. Appelmelk et al., Mycobacteria target DC-SIGN to suppress dendritic cell function, J Exp Med 197 (2003), pp. 7-17. View Record in Scopus I Cited By in Scopus (433)

$\underline{89}$ L. Tailleux, O. Schwartz, J.L. Herrmann, E. Pivert, M. Jackson and A. Amara et al., DC-SIGN is the major Mycobacterium tuberculosis receptor on human dendritic cells, J Exp Med 197 (2003), pp. 121-127.

90 P.B. Kang, A.K. Azad, J.B. Torrelles, T.M. Kaufman, A. Beharka and E. Tibesar et al., The human macrophage mannose receptor directsMycobacterium tuberculosis lipoarabinomannanmediated phagosome biogenesis, J Exp Med 202 (2005), pp. 987-999. Full Text via CrossRef I View Record in Scopus I Cited By in Scopus (81)

91 N. Maeda, J. Nigou, J.L. Herrmann, M. Jackson, A. Amara and P.H. Lagrange et al., The cell surface receptor DC-SIGN discriminates between mycobacterium species through selective recognition of the mannose caps on lipoarabinomannan, J Biol Chem 278 (2003), pp. 55135516. Full Text via CrossRef I View Record in Scopus I Cited By in Scopus (100)

92 A. Sinha, A. Singh, V. Satchidanandam and K. Natarajan, Impaired generation of reactive oxygen species during differentiation of dendritic cells (DCs) by Mycobacterium tuberculosis secretory antigen (MTSA) and subsequent activation of MTSA-DCs by mycobacteria results in increased intracellular survival, J Immunol 177 (2006), pp. 468478. View Record in Scopus I Cited By in Scopus (11)

93 D.R. Green, T. Ferguson, L. Zitvogel and G. Kroemer, Immunogenic and tolerogenic cell death, Nat Rev Immunol 9 (2009), pp. 353-363. Full Text via CrossRef I View Record in Scopus I Cited By in Scopus (51)

94 M.B. Torchinsky, J. Garaude, A.P. Martin and J.M. Blander, Innate immune recognition of infected apoptotic cells directs T(h)17 cell differentiation,Nature 458 (2009), pp. 78-82. Full Text via CrossRef I View Record in Scopus I Cited By in Scopus (44)

95 M. Oddo, T. Renno, A. Attinger, T. Bakker, H.R. MacDonald and P.R. Meylan, Fas ligandinduced apoptosis of infected human macrophages reduces the viability of intracellular Mycobacterium tuberculosis, J Immunol 160 (1998), pp. 5448-5454. View Record in Scopus I Cited By in Scopus (166)

96 H. Pan, B.S. Yan, M. Rojas, Y.V. Shebzukhov, H. Zhou and L. Kobzik et al., Ipr1 gene mediates innate immunity to tuberculosis, Nature 434 (2005), pp. 767-772. View Record in Scopus I Cited By in Scopus (107)

97 U.E. Schaible, F. Winau, P.A. Sieling, K. Fischer, H.L. Collins and K. Hagens et al., Apoptosis facilitates antigen presentation to $\mathrm{T}$ lymphocytes through $\mathrm{MHC}-\mathrm{I}$ and $\mathrm{CD} 1$ in tuberculosis, Nat Med 9 (2003), pp. 1039-1046. Full Text via CrossRef I View Record in Scopus I Cited By in Scopus (193) 
98 F. Winau, S. Weber, S. Sad, J. de Diego, S.L. Hoops and B. Breiden et al., Apoptotic vesicles cross prime CD8 T cells and protect against tuberculosis,Immunity 24 (2006), pp. 105-

117. Article I PDF (595 K) I View Record in Scopus I Cited By in Scopus (97)

99 M. Chen, H. Gan and H.G. Remold, A mechanism of virulence: virulent Mycobacterium tuberculosis strain H37Rv, but not attenuated H37Ra, causes significant mitochondrial inner membrane disruption in macrophages leading to necrosis, J Immunol 176 (2006), pp. 37073716. View Record in Scopus I Cited By in Scopus (32)

100 M. Divangahi, M. Chen, H. Gan, D. Desjardins, T.T. Hickman and D.M. Lee et al., Mycobacterium tuberculosis evades macrophage defenses by inhibiting plasma membrane repair, Nat Immunol 10 (2009), pp. 899-906. Full Text via CrossRef I View Record in Scopus I Cited By in Scopus (10)

101 H. Gan, J. Lee, F. Ren, M. Chen, H. Kornfeld and H.G. Remold, Mycobacterium tuberculosis blocks crosslinking of annexin-1 and apoptotic envelope formation on infected macrophages to maintain virulence, Nat Immunol 9 (2008), pp. 1189-1197. Full Text via CrossRef I View Record in Scopus I Cited By in Scopus (22)

102 J. Keane, H.G. Remold and H. Kornfeld, Virulent Mycobacterium tuberculosis strains evade apoptosis of infected alveolar macrophages, J Immunol164 (2000), pp. 2016-2020. View Record in Scopus I Cited By in Scopus (178)

103 K. Velmurugan, B. Chen, J.L. Miller, S. Azogue, S. Gurses and T. Hsu et al., Mycobacterium tuberculosis nuog is a virulence gene that inhibits apoptosis of infected host cells, PLoS Pathog 3 (2007), p. e110. Full Text via CrossRef I View Record in Scopus I Cited By in Scopus $\underline{(25)}$

104 D. Jayakumar, W.R. Jacobs Jr. and S. Narayanan, Protein kinase E of Mycobacterium tuberculosis has a role in the nitric oxide stress response and apoptosis in a human macrophage model of infection, Cell Microbiol 10 (2008), pp. 365-374. View Record in Scopus I Cited By in Scopus (8)

105 S. Kurtz, K.P. McKinnon, M.S. Runge, J.P. Ting and M. Braunstein, The SecA2 secretion factor of Mycobacterium tuberculosis promotes growth in macrophages and inhibits the host immune response, Infect Immun 74 (2006), pp. 6855-6864. Full Text via CrossRef I View Record in Scopus I Cited By in Scopus (22)

106 J. Hinchey, S. Lee, B.Y. Jeon, R.J. Basaraba, M.M. Venkataswamy and B. Chen et al., Enhanced priming of adaptive immunity by a proapoptotic mutant of Mycobacterium tuberculosis, J Clin Invest 117 (2007), pp. 2279-2288. Full Text via CrossRef I View Record in Scopus I Cited By in Scopus (58)

107 V. Briken and J.L. Miller, Living on the edge: inhibition of host cell apoptosis by Mycobacterium tuberculosis, Future Microbiol 3 (2008), pp. 415-422. Full Text via CrossRef I View Record in Scopus I Cited By in Scopus (6)

108 M. Kundu, S.K. Pathak, K. Kumawat, S. Basu, G. Chatterjee and S. Pathak et al., A TNF- and C-cbl-dependent FLIP(s)-degradation pathway and its function in Mycobacterium tuberculosisinduced macrophage apoptosis, Nat Immunol 10 (2009), pp. 918-926. Full Text via CrossRef I View Record in Scopus I Cited By in Scopus (4)

109 M.K. Balcewicz-Sablinska, J. Keane, H. Kornfeld and H.G. Remold, Pathogenic mycobacterium tuberculosis evades apoptosis of host macrophages by release of TNF-R2, resulting in inactivation of TNF-alpha, J Immunol 161 (1998), pp. 2636-2641. View Record in Scopus I Cited By in Scopus (183) 
110 J.L. Miller, K. Velmurugan, M.J. Cowan and V. Briken, The type I NADH dehydrogenase of Mycobacterium tuberculosis counters phagosomal NOX2 activity to inhibit TNF-alphamediated host cell apoptosis, PLoS Pathog 6 (2010), p. e1000864. Full Text via CrossRef I View Record in Scopus | Cited By in Scopus (0)

111 R. Dhiman, M. Raje and S. Majumdar, Differential expression of NF-kappa B in mycobacteria infected THP-1 affects apoptosis, Biochim Biophys Acta1770 (2007), pp. 649658. Article I PDF (1240 K) | View Record in Scopus | Cited By in Scopus (13)

112 L.M. Sly, S.M. Hingley-Wilson, N.E. Reiner and W.R. McMaster, Survival of Mycobacterium tuberculosis in host macrophages involves resistance to apoptosis dependent upon induction of antiapoptotic bcl-2 family member mcl-1, J Immunol 170 (2003), pp. 430-437. View Record in Scopus I Cited By in Scopus (70)

113 J. Lee, H.G. Remold, M.H. leong and H. Kornfeld, Macrophage apoptosis in response to high intracellular burden of Mycobacterium tuberculosis is mediated by a novel caspaseindependent pathway, J Immunol 176 (2006), pp. 4267-4274. View Record in Scopus I Cited By in Scopus (46)

114 M.P. O'Sullivan, S. O'Leary, D.M. Kelly and J. Keane, A caspase-independent pathway mediates macrophage cell death in response toMycobacterium tuberculosis infection, Infect Immun 75 (2007), pp. 1984-1993.

115 A.B. Yadav and A. Misra, Enhancement of apoptosis of THP-1 cells infected with Mycobacterium tuberculosis by inhalable microparticles and relevance to bactericidal activity, Antimicrob Agents Chemother 51 (2007), pp. 3740-3742. Full Text via CrossRef I View Record in Scopus I Cited By in Scopus (4)

116 A.B. Yadav, P. Muttil, A.K. Singh, R.K. Verma, M. Mohan and A.K. Agrawal et al., Microparticles induce variable levels of activation in macrophages infected with Mycobacterium tuberculosis, Tuberculosis (Edinb) 90 (2010), pp. 188-196. Article I PDF (416 K) I View Record in Scopus | Cited By in Scopus (0) 